\title{
Case studies and case reports. Management and legal orientations to text
}

\section{Simonetta Resta}

\section{(2) OpenEdition}

\section{Journals}

\section{Electronic version}

URL: http://journals.openedition.org/asp/3428

DOI: $10.4000 / a s p .3428$

ISSN: 2108-6354

\section{Publisher}

Groupe d'étude et de recherche en anglais de spécialité

\section{Printed version}

Date of publication: 1 December 1996

Number of pages: $55-74$

ISSN: 1246-8185

\section{Electronic reference}

Simonetta Resta, « Case studies and case reports. Management and legal orientations to text », ASp

[Online], 11-14 | 1996, Online since 23 April 2013, connection on 19 April 2019. URL : http:// journals.openedition.org/asp/3428 ; DOI : 10.4000/asp.3428

This text was automatically generated on 19 April 2019.

Tous droits réservés 


\title{
Case studies and case reports. Management and legal orientations to text
}

\author{
Simonetta Resta
}

\section{Introduction}

1 We take it as axiomatic that communication in human societies takes place 1) in the context of social occasions which are reflected in 2) conventional genres which are expressed in 3) attitudinal discourse which is realised in 4) communicative, goal-oriented text.

2 We further assume (in a rather conservative way and only for the time being) that the major focus of linguistics is to describe and explain the nature of text -the last of the four levels above- leaving the remaining three areas within the domains of the other human sciences: anthropology, sociology, social-psychology etc.

Specifically (and still very conservatively) linguistics considers a) that language is the system by means of which text is produced, $b$ ) that language is a code which possesses formal features (phonological -and, in the case of written languages, graphologicalsyntactic, lexical and semantic), c) that language can be treated as a context-free closed system and d) that language use is made possible by making selections from amongst these sets of code features in order to create texts which act as adequate vehicles for the communication of meaning (i.e. which function as discourse).

4 However, such a formalist view of the boundaries of linguistics necessarily limits the professional expertise of the linguist (qua linguist) in ways which embargo the study of the context-sensitive, open-system, functional aspects of language. To venture beyond the traditional levels of linguistic analysis (syntax -including both lexis and cohesion- and semantics) to consider the setting of the text in time and space or the participants involved in its production and reception is seen, from this perspective, as venturing into fields in which the linguist is, professionally speaking, an amateur. The amateur has, of necessity, 
limited -certainly stereotyped and potentially highly inaccurate- knowledge of the expert's field and this, again necessarily, limits and confuses the interpretation of the specialised text. The schema of the expert is far richer, extensive and co-ordinated than that of the non-expert. The expert is an "insider"; a privileged member of an exclusive professional network to which the non-expert has, at best, strictly limited access. The non-expert can perceive (in the terms suggested by Pike (1967) based on the analogy with phonetic and phonemic) the etic of any text or situation (what it contains; what happens) but not the emic (the structure of the whole set in its professional context; the why of the event).

5 However, to placidly accept such a view would have several (in our opinion, regrettable) effects. It would 1) limit any discussion of meaning to the semantic sense of each word and sentence (the "brute facts", as Searle (1969) called them) and preclude any consideration of its communicative value (Searle's "institutional facts"); an enterprise which would be (again in Searle's words) about as revealing as describing football without any reference to the rules of the game 2) prevent any study of what we would certainly expect to find, in any stretch of language; choices which function as indicators of the temporal, physical and social provenance of the user (dialect features) and markers of the use to which the language was being put (register features).

6 In support of the formalist orientation, it could be argued that the linguist is in a position analogous to the digger on an archaeological site; (s)he can find and describe facts in terms of their formal characteristics but cannot (strictly speaking), as linguist ${ }_{2}$ explain why these facts are as they are or what their function might be. That, it would be argued, is the prerogative of the archaeologist.

In defence of a broader-based approach, we might counter this argument by pointing to the well-established example of the stylistician whose work on literary texts combines the often highly sophisticated display of recurring patterning with sensitive critical insight; the linguist can also be a critic and the digger an archaeologist. There is, indeed, evidence in the development of forensic linguistics within the legal process itself (see Coulthard 1994) of individuals who, like the stylistician, combine the expertise of the legal scholar with that of the linguist or that of the linguist with the legal scholar. It is precisely in such a spirit of compromise and intended collaboration that this paper has been written.

\section{A linguistic approach to text and discourse analysis}

8 Even if we accept, for the sake of argument, that the professional expertise of the linguist is in what is frequently termed "core linguistics" - the formal aspects of language: syntax and semantics (cohesion, at the level of text) - and the lawyer's or management scientist's in semiotics -the functional aspects of language; pragmatics and semantics (coherence, at the level of discourse) - there is still a justification for linguists seeking to contextualise texts so that they can be understood as context-sensitive discourse. Linguistics clearly have a right to attempt to broaden the scope of linguistics in this direction and there have been major developments since the 1960s.

9 The key characteristics of this approach have been 1) the creation of an interlevel (discourse) between the linguistic and the extra-linguistic and the attempt to demonstrate the relations between linguistic usage on the one hand and social and 
communicative use on the other. The right to attempt this is -we might claim-inalienable but the right to be taken seriously by the experts into whose domains linguistics is attempting to expand is not. We can have some degree of faith in linguists getting their facts right but rather less in the validity of their evaluation of those facts in terms of the context of their use.

In essence, the problem which faces the text-analyst is three-fold: 1) to describe the formal linguistic features (which, by their very nature, are discrete) which combine to create the text, 2) to discover the functional sociological variables (which, by their very nature, are ranged along a continuum rather than being discrete items) present in i) the participants (their role relationships), ii) the purposes they bring to the event (the "symbolic or rhetorical channel") and iii) the setting of the event (the "on-going social activity") and 3) to relate the formal (linguistic) and functional (sociological) evidence in a way which shows how the text is realised in, and as, interaction (discourse); i.e., relating discrete (all-or-none) linguistic code items to non-discrete (continuum, more-or-less) extra-linguistic social features in ways which reveal the relationships between structure, text and discourse.

Given this three-term system, it seems wise to give some working definitions and examples of each.

\subsection{Text, discourse and structure} language; Halliday 1985) the THEME systems of the grammar; a unit which carries the semantic sense of the proposition (the propositional content and locutionary force of the speech act) through clauses which are linked by means of coHEsIon i.e. a structured sequence of linguistic expressions forming a unitary whole.

14 Discourse is a communicative event which draws on the meaning potential of the language (and other systems of communication) to convey communicative value (the illocutionary force of the speech act) through utterances which are linked by COHERENCE i.e., a structured event manifest in linguistic (and other) behaviour.

15 Structure is achieved through the linguistic co-text, in the case of TEXT and the nonlinguistic social context, in the case of DISCOURSE.

\subsection{Parameters of variation}

16 The questions that a functional analysis, if a text would ask to take understanding beyond the formal structure of the text, can be neatly stated by building a light-hearted model provided by Kipling's Six honest servingmen:

I keep six honest servingmen

(They taught me all I knew);

Their names were What? and Why? and When?

And How? and Where? and Who?

17 Each of these "names" defines one (or more) of the questions we need to probe a text and provides us with a set of parameters of variation. 
1. What? is the message contained in the text; the content of the signal; the propositional content of the speech acts.

2. Why? orients us towards the intention of the sender; the purpose for which the text was issued (spoken or written), the illocutionary forces of the speech acts which constitute the underlying structure of the text; the discourse. These run the whole gamut from informing through persuading to flattering...and, as we shall see, it is rare for a text to possess a single function. Multiple functions are the norm rather than the exception for adult language, so our task as receivers of texts, is to tease out the primary function (the rhetorical purpose of the text) from those which are secondary; a fundamental difficulty when we attempt to devise a text-typology.

3. When? is concerned with the time of the communication realised in the text and placing it in its historical context; contemporary or set in the recent or remote past or future.

4. How? is ambiguous, since it can refer to: a) manner of delivery; the tenor of the discourse; serious or flippant or ironic... or b) medium of communication; the mode of the discourse; the channel(s) - verbal/non-verbal, speech/ writing- selected to carry the signal.

5. Where? is concerned with the place of the communication; the physical location of the speech event realised in the text.

6. Who? refers to the participants involved in the communication; the sender and receiver(s). Both spoken and written texts will reveal, to a greater or lesser extent, characteristics of the speaker or writer as an individual and also, by inference, the attitude the sender adopts in relation to the receiver(s) and to the message being transmitted.

These six questions subdivide into three major parameters of variation: 1 and 2 into domain, 3, 4, 5 and 6 into tenor and, because of the ambiguity of the term "how" (means or manner), 4 divides again into mode.

Each of these parameters (not discrete points but, it must be remembered, a continuum) subdivides, respectively, into 1) six communicative functions, 2) four markers of participant relationships: addresser and addressee(s) and 3) four markers of the relationship between participants and the medium used in the communication.

Table 1

\begin{tabular}{|l|l|l|}
\hline 1 & Domain & language used to: \\
\hline 1.1 & conative & influence others; e.g., persuade, instruct, order, regulate \\
\hline 1.2 & emotive & express personal feelings; e.g., health, state of mind \\
\hline 1.3 & metalinguistic & $\begin{array}{l}\text { talk about language; e.g., dictionaries and grammars, self-monitoring of } \\
\text { speech }\end{array}$ \\
\hline 1.4 & phatic & $\begin{array}{l}\text { draw attention to the fact of contact and communication; e.g., greetings, } \\
\text { telephone channel clearing ('hello'), discussion of weather (in English) }\end{array}$ \\
\hline 1.5 & poetic & $\begin{array}{l}\text { focus attention on the message; e.g., literary texts, joke- and story- } \\
\text { telling }\end{array}$ \\
\hline
\end{tabular}




\begin{tabular}{|c|c|c|}
\hline 1.6 & referential & $\begin{array}{l}\text { refer to phenomena; entities, states, events and relationships of the } \\
\text { perceptual world }\end{array}$ \\
\hline 2 & Tenor & $\begin{array}{l}\text { language used to reflect the relationship between the sender and } \\
\text { receiver(s) of messages and reflected in degrees of: }\end{array}$ \\
\hline 2.1 & accessibility & $\begin{array}{l}\text { extent to which receiver (reader-listener) can comprehend the text; } \\
\text { writer's assumptions about shared knowledge signalled by extent of } \\
\text { explicitness, use of technical terminology }\end{array}$ \\
\hline 2.2 & formality & $\begin{array}{l}\text { attention paid by the sender to the structuring of the message and } \\
\text { signalled by choices of lexical items and syntactic structures }\end{array}$ \\
\hline 2.3 & impersonality & $\begin{array}{l}\text { avoidance of self- and receiver- reference in the text; achieved by e.g. } \\
\text { passive structures, avoidance of pronouns such as I, we, you: typified by } \\
\text { academic, bureaucratic, scientific text }\end{array}$ \\
\hline 2.4 & politeness & $\begin{array}{l}\text { distance between sender and receiver; horizontal (between social } \\
\text { groups), vertical (between individuals in terms of seniority, status, } \\
\text { power...) e.g. address forms using titles/first names/ surnames/ } \\
\text { combinations of these ... }\end{array}$ \\
\hline 3 & $\begin{array}{l}\text { Mode (degrees } \\
\text { of) }\end{array}$ & $\begin{array}{l}\text { language used to reflect degrees of influence caused by the medium of } \\
\text { communication: }\end{array}$ \\
\hline 3.1 & $\begin{array}{l}\text { channel } \\
\text { limitation }\end{array}$ & $\begin{array}{l}\text { single or multiple channel communication; contrast writing (visual } \\
\text { only) and speaking (aural, visual, tactile...) }\end{array}$ \\
\hline 3.2 & participation & $\begin{array}{l}\text { feedback and role shift - speaker to hearer and back - contrast the } \\
\text { written text with the spoken and the monologue with the relaxed } \\
\text { conversation. }\end{array}$ \\
\hline 3.3 & privateness & $\begin{array}{l}\text { number of intended addresses; the more receivers, the less private. } \\
\text { Contrast the private letter with the Highway Code. }\end{array}$ \\
\hline 3.4 & spontaneousness & $\begin{array}{l}\text { extent of preparation prior to the issuing of the text; speech is typically } \\
\text { unprepared, writing typically pre-planned even rewritten }\end{array}$ \\
\hline
\end{tabular}

\section{Two texts}

We shall make use of these parameters -and, in addition, such notions as lexical density, lexical novelty, word frequency, collocation, stylistic structures- all of which have been found to be revealing in the forensic analysis of texts (Coulthard 1992: 19-20).

\subsection{Legal text: from a case study in precedent}

If your Lordships accept the view that the appellant's pleading discloses a relevant cause of action, you will be affirming the proposition that by Scots and English law alike a manufacturer of products which he sells in such a form as to show that he intends them to reach the ultimate consumer in the form in which they left him, 
with no reasonable possibility of intermediate examination, and with the knowledge that the absence of reasonable care in the preparation or putting up of the products will result in injury to the consumer's life or property, owes a duty to the consumer to take that reasonable care.

\subsubsection{Formal features} profession.

and reads

The most obvious formal features in this text are the lexically specialised terms such as affirm, appellant, disclose, plead etc. which, together with the naming of the addressees as your Lordships and the reference to Scots and English Law clearly fixes the text within the domain of legal language. Less obvious, but no less significant, is the use of apparently "ordinary" terms in "non-ordinary", specialised ways e.g. duty and reasonable (which occurs no less than three times). Such lexical usages are typical of technical discourse of all kinds (including science, criticism and -as we shall see below- management) in which they have the dual, and opposite, effect of reducing accessibility for the general, non-expert reader/hearer, while easing comprehension for the expert member of the

However, an assessment of lexical novelty reveals that the text is below the anticipated average for types as a percentage of tokens in a text. As Coulthard (1992) tells us,

...in any text or corpus of whatever length, be it 150, 150 thousand or even 150 million words long, roughly half of all the words (types not tokens) occur only once. However, there are sometimes interesting individual deviations from this norm: ...a highly articulate speaker/writer may use a disproportionately large percentage of once-only words...

In this text, the percentage is more than $10 \%$ below the expected $50 \%$ at $39.25 \%$. The writer is not acting as a highly articulate speaker/writer and engaging in lexical novelty; repetition of items id, clearly, the case here.

The syntactic structure is particularly interesting. The text consists of a single highly complex sentence with a chain of functional "slots" consisting of initial Adjunct (a subordinate if clause), Subject, Predicator, Object. This is, of course, a far from unusual syntactic chain for English. What is unusual, however, and the cause of such difficulty for the non-expert reader is the quantity of the items which are chosen to fill each element of the chain. Again, typically for much technical writing, the number of words in each of the four functional slots is significant: $16,1,3$ and 87 i.e. a single lexical item (the pronoun you) realising the Subject and only three the Predicator (indeed, it does not seem that it would have changed the meaning significantly if the Predicator had been realised by the single item affirm). The complexity, then, resides in the Object (a noun phrase with a series of five embedded qualifiers which are themselves clauses) and, to a lesser extent, in the Adjunct -the initial subordinate (if) clause- with its sixteen words and complex Object (a NP consisting of a rankshifted clause as qualifier).

However, shorn of its qualifications and reduced to the proposition which underlies it, the sentence consists of the simple logical structure:

if you agree $\mathrm{x}$, you affirm $\mathrm{y}$

if you accept this, you will be affirming the proposition that a manufacturer owes a

duty to the customer to take...reasonable care.

The addition of the qualifications makes the structure, demonstrably, very "end-heavy" (the term manufacturer -the person about whose behaviour the case is concerned-being 
separated from the verb which it relates to by no less than 65 words; considerably more than half the text. Even so and perhaps surprisingly, the text is relatively easy to process and this is because the qualifications are cumulative and organised by clause structures which are, essentially, right-branching rather than left (post- rather than premodification) and do not need to be held in the short-term working memory for a long period of time.

This, in a nutshell, is a description of how the text is structured and a suggestion how it might affect the non-expert reader. It does not explain why the text should be structured in this way and why expert readers not only do not find difficulty with it but actually find it easy to process. The competence of the linguist lies in description not explanation. Explanation is the prerogative of the legal scholar (see section 3 below).

The modality (see Bell 1991: 139-141 for the distinction between modality and modulation) of the text is of considerable interest, since there is no attempt whatsoever on the part of the writer to provide an assessment of the extent to which the assertions being made in the text are probable or usual i.e. modality (even in the two instances where modality is marked by a modal verb) is neutral; you will be affirming, will result... Significantly, the only modification in the text which might be construed as possessing some degree of modality is found - on three occasions-in the word reasonable (possibility/ care); itself (though this is far from transparent to the non-expert reader) a highly technical term in Common Law.

Modulation, however, is another matter. The whole thrust of the argument in the text is encapsulated in the phrase owes a duty to and the text is structured in such a way as to provide argument which leads directly to that conclusion.

Textual cohesion is achieved, almost exclusively, by means of the reiteration of lexical items (or cognates of them) or the use of nominal proforms. Thus we find each of the protagonists stated and restated in the text: your Lordships + you, appellant + manufacturer + he + him, products + them, consumer, care. Strikingly, the only example of junction is the occurrence of a single and linking two Adjuncts (Prepositional Phrases): with no reasonable possibility of intermediate examination, and with the knowledge that the absence of reasonable care...

\subsubsection{Discourse features}

Table 2

\begin{tabular}{|l|l|l|}
\hline 1 & Domain & \\
\hline 1.1 & conative & yes; to persuade the addressee to accept the addresser's argument \\
\hline 1.2 & emotive & no; far from it! \\
\hline 1.3 & metalinguistic & $\begin{array}{l}\text { not in this case but legal language is often concerned with defining } \\
\text { terms }\end{array}$ \\
\hline 1.4 & phatic & no \\
\hline 1.5 & poetic & no \\
\hline
\end{tabular}




\begin{tabular}{|c|c|c|}
\hline 1.6 & referential & $\begin{array}{l}\text { necessarily so (all texts refer to something); a case = consisting of } \\
\text { participants and their actions = and a proposition derived from previous } \\
\text { cases. }\end{array}$ \\
\hline 2 & $\begin{array}{l}\text { Tenor (degrees } \\
\text { of) }\end{array}$ & \\
\hline 2.1 & accessibility & $\begin{array}{l}\text { low for general public but high for intended addressees; members of the } \\
\text { legal profession }\end{array}$ \\
\hline 2.2 & formality & $\begin{array}{l}\text { complex syntax indicates extreme care in preparing the text; it is, } \\
\text { indeed, a "prepared statement" which the author (a judge) considers to } \\
\text { be of great importance and, therefore, worthy of careful writing and } \\
\text { reading }\end{array}$ \\
\hline 2.3 & impersonality & $\begin{array}{l}\text { less impersonal than might be expected. The writer avoids reference to } \\
\text { himself but does address the receivers of the text (other judges) directly; } \\
\text { Your Lordships, you }\end{array}$ \\
\hline 2.4 & politeness & $\begin{array}{l}\text { only on the axis of vertical distance (indicated by the use titles) because } \\
\text { the power relationship between the participants is asymmetrical (the } \\
\text { writer is attempting to persuade the Court of Appeal whose decision it } \\
\text { will be and who are, on this occasion, his superiors) rather than } \\
\text { horizontal (socially, the addresser and addressees are social equals; } \\
\text { senior members of the legal profession) }\end{array}$ \\
\hline 3 & $\begin{array}{l}\text { Mode (degrees } \\
\text { of) }\end{array}$ & \\
\hline 3.1 & $\begin{array}{l}\text { channel } \\
\text { limitation }\end{array}$ & $\begin{array}{l}\text { low, since the address forms suggest face-to-face spoken communication } \\
\text { in which multiple channels are available. However, without additional } \\
\text { context (which the legal expert would, of course, be aware of) the } \\
\text { analyst cannot be certain if the text is, in fact, a transcript of speech or a } \\
\text { written text which was never spoken, or - between the two- a written } \\
\text { text which is written to be spoken i.e. to be read out. }\end{array}$ \\
\hline 3.2 & participation & $\begin{array}{l}\text { low since it is an uninterrupted non-spontaneous monologue which may } \\
\text { or may not form part of a more extensive dialogue }\end{array}$ \\
\hline 3.3 & privateness & low since it is (and is intended to be) a public statement \\
\hline 3.4 & spontaneousness & $\begin{array}{l}\text { preplanned and the result of a substantial period of research, discussion } \\
\text { and redrafting }\end{array}$ \\
\hline
\end{tabular}

\subsection{Management text: case study in business}

Troubled times for Benson Group

When Benson announces its annual results on Wednesday, it is expected that the group's profits will be around $\$ 6 \mathrm{~m}$. This will mean a drop of some $25 \%$ compared with the previous year. Today, Benson's share price fell to just under $\$ 7$ in 
anticipation of the results. Two or three years ago, it will be recalled, the share price stood at $\$ 10$.

One of Benson's biggest problems is that it lacks a clear image. Although some welloff customers have stuck with Benson through thick and thin, many others have moved on and now shop at Hi-Mark These customers seem to prefer Hi-Mark's tasteful decor and high-priced, exclusive goods. Another of Benson's disadvantages is that its merchandise does not particularly appeal to younger buyers/ These prefer the self-service, down-market approach of Levinson Brothers - Benson's other main rival. Both Hi-Mark and Levinson Brothers are profitable organisations. Hi-Mark's strategy is, essentially, to maintain good profit margins on all its merchandise. Levinson Brothers, on the other hand, aim for high volume and lower margins.

All three organisations $=$ Benson, Hi-Mark and Levinson Brothers $=$ face a common problem. They are all aware of the threat coming from the new multiple stores retailers like Klassic, Marginal and Clique. These are "muscling in" on the other groups' traditional markets for clothing, home decoration and food. The new multiples have been very successful at attracting to their stores fashion-conscious customers, both young and old. They seem to have the knack of offering exciting, stylish goods at prices people can afford.

Rising costs have been the main cause of Benson's low profits. Stock levels tend to be high, but very often goods are not available when required by customers. At present, goods are kept in warehouses at each store. Benson are considering changing this system. It may build one or two huge distribution centres which will supply all the stores. This could be a less costly way of organising its warehousing facilities. In addition, it has been suggested that service at Benson's stores is not what it used to be. It is believed, also, that staff turnover and absenteeism is too high.

Unless Benson's management take action soon to revive the group's fortunes, it would seem that the outlook for the organisation is bleak.

\subsubsection{Formal features}

In contrast with the legal text, this management text contains no particularly impervious terminology to mark it off from relaxed - relatively informal and accessible- writing. There are, indeed, actually instances of elements which could easily occur in relaxed spontaneous speech (e.g. through thick and thin, muscling in on); again in marked contrast with the legal text where it is inconceivable that the writer could have spoken the text without substantial preparation and, even, rehearsal.

The text also has a title (a minor clause) and its 382 words distributed over 25 very simple sentences; an average of 10.81 words per sentence (including the title clause). If such a ratio were typical of legal texts as well, we should have expected the 106 word legal sample above to have consisted of between 9 and 10 sentences. Put another way, if the conventions of legal writing - as exemplified by the sample we have used-were applied to this management text, it would consist of between two and three sentences; sentences of far greater complexity than we find in the actual management text.

Lexical novelty -measured in terms of types as a percentage of tokens- is, perhaps surprisingly, even further from the norm than it is in the legal text i.e. 35.6\%; the writer is hammering home the key items by repetition: Benson, High-Mark and LevinsonBrothers (or co-referential terms for them) together occurring no less than 30 times.

The specific syntax of the individual sentences ranges from very simple to moderately complex. The title (a minor clause) consists (at surface level) of a single NP functioning 
(presumably) as $\mathrm{C}$ which, through ellipsis, can be read as something like (These are) troubled times for (the) Benson group: SPC.

The sentences are typically SPO or (a preponderance of) SPC. Cohesion is overt and varied. Virtually every one of the 13 possible cohesive devices available in English (from reference, through substitution, ellipsis and junction to lexical cohesion; see Bell 1991: 154-156 for a list, examples and discussion) are made use of and it is in this diversity of cohesive devices that the management text contrasts very markedly with the legal text in which cohesion is achieved almost exclusively by lexical substitution and reiteration.

Linkage between sentences is also frequently overt. For example, 8 of the 25 sentences have initial A (half of which are rank-shifted clauses) acting as cohesive devices. None the less, even taking into account the rankshifted clause at $\mathrm{A}$, there is little subordination. What there is tends to be right-branching relative clauses (e.g. ...stylish goods at prices people can afford), or (less commonly) more complex direct embeddings (e.g. Hi-Marks's strategy is, essentially, to maintain good profit margins...). Co-ordination, both within and between sentences, is relatively uncommon.

The modality of the text is particularly interesting; although the text is strongly assertive, almost one third of the verbs express weak commitment either directly or through modal verbs or adverbs e.g. seem, tend, suggest...could, may...does not particularly appeal...).

In short, although the bald statement that the text consists of 25 relatively simple sentences with an average length of 10.81 words is essentially correct, it conceals the fact that sentence length varies around that mean on a range extending from as low as 5 (in the title) to as high as 22 words (final sentence) and that even though the text is typified by such sentences as At present, goods are kept in warehouses at each store (a straight-forward ASPAA structure) sentence complexity can be considerable e.g. Unless Benson's management take action soon to revive the group's fortunes, it would seem that the outlook for the organisation is bleak (a complex A SPC structure. In this 1) the initial A is itself a clause with a ASPAO structure within which the $\mathrm{O}$ is realised as a clause with the structure $\mathrm{PO}$ and 2) the $\mathrm{C}$ of the main clause is also a rankshifted clause; conj. SPC.

\subsubsection{Discourse features}

Table 3. Discourse features

\begin{tabular}{|l|l|l|}
\hline 1 & Domain & \\
\hline 1.1 & conative & $\begin{array}{l}\text { covertly so, since the text presents an argument with the implicit } \\
\text { intention of persuading reader(s) of the correctness of the analysis and } \\
\text { accuracy of the prediction }\end{array}$ \\
\hline 1.2 & emotive & no \\
\hline 1.3 & metalinguistic & no \\
\hline 1.4 & phatic & no \\
\hline 1.5 & poetic & no \\
\hline
\end{tabular}




\begin{tabular}{|c|c|c|}
\hline 1.6 & referential & $\begin{array}{l}\text { highly referential; participants, setting, processes all stated within the } \\
\text { context of the argument }\end{array}$ \\
\hline 2 & $\begin{array}{l}\text { Tenor (degrees } \\
\text { of) }\end{array}$ & \\
\hline 2.1 & accessibility & $\begin{array}{l}\text { highly accessible to the general reader; contrast the legal text which } \\
\text { was narrowly oriented to the profession itself }\end{array}$ \\
\hline 2.2 & formality & $\begin{array}{l}\text { By no means informal but carefully crafted to give the impression of } \\
\text { nonchalant carelessness which permits easy reading; a function, } \\
\text { however, of the adage 'easy read; hard write' }\end{array}$ \\
\hline 2.3 & impersonality & high; the writer refers directly neither to him/herself nor to the reader \\
\hline 2.4 & politeness & $\begin{array}{l}\text { on the vertical axis (authority) but not horizontal (class); the writer -a } \\
\text { business journalist- is addressing assumed social equals who (so to } \\
\text { speak, since they buy the paper) employ him. }\end{array}$ \\
\hline 3 & $\begin{array}{l}\text { Mode (degrees } \\
\text { of) }\end{array}$ & \\
\hline 3.1 & $\begin{array}{l}\text { channel } \\
\text { limitation }\end{array}$ & limited since the text is on which has been written to be read (silently) \\
\hline 3.2 & participation & none; the text is a pure monologue \\
\hline 3.3 & privateness & $\begin{array}{l}\text { not at all private; substantial potential addressees are catered for (and } \\
\text { hoped for by the publishers). This, therefore, a highly public document. }\end{array}$ \\
\hline 3.4 & spontaneousness & Carefully prepared and, no doubt, the end result of several rewrites. \\
\hline
\end{tabular}

\section{A semiotic approach to text and discourse analysis}

\subsection{Language as social practice}

If we reconsider the analysis of the two texts carried in the previous part of this paper (section 1.1.2.2), it mainly provides a thorough description of the text as a formal product and a lexico-grammatical entity typically analysed in terms of three variables: field, tenor and mode but does not provide an explanation which sheds light on the interaction of the communicative event connected to a social occasion of legal and economic discourse.

Linguistics (see the introduction) provides a description and explanation of the productive and interpretative processes of the text but does not provide any description or explanation of the communicative events in its global aspect (social occasion, discourse, its author and intended reader). Hence it does not take into account the fact that lexical and syntactic choices made within (the Field, Mode, and Tenor of) a given discourse are determined by pragmatic considerations as to the purposes of utterances and real world-conditions. Hence we need to understand not only the pragmatic action 
but also the semiotic dimension which regulates the interaction of the various discoursal elements as "signs".

Language perceives and registers all social trends and practices through which patterns of living and value are established and it is a powerful tool of expression of the ideologies and conflicts of society as the dynamic formation of relationships and practices such as professions and the institutions. (Fairclough 1989).

Discourse operates within conventions defined by the "discourse community". The discourse community is seen as academic discipline or social groups. The discourse community together with the concept of specific interest group. Swales offers a more identifiable aspect and reference to identify social occasions and discourses generated by them:

[...] that language use in a group is a form of social behaviour, that discourse is a means of maintaining and extending the group's knowledge and of initiating new member into the group, and that discourse is epistemic or constitutive of the group's knowledge. (1985: 250)

Language is social practice and it is conditioned by other non-linguistic factors in society, and differs in the way they perceive and partition reality, creating not only cross-cultural differences but problems of understanding within a single language. Sometimes to understand the purpose of an utterance not only an intersemiotic but also a kind of intrasemiotic translation is needed. Any analysis which does not consider this interactive dimension which takes place between various signs within the texts and the producer of these signs and the intended receiver (the three stages of the communication scheme :social occasion, genres and attitudinal discourse (see Introduction) is not complete as it is carried out by an outsider who does not venture into the expert field.

\subsection{Genre and register}

For a distinction between genre and register see Swales (1993: 40). The first imposes constraints at the linguistic level of vocabulary and syntax, whereas the second implies constraints, at the discourse level. It is important to stress that both notions are equally useful for describing a text, as we have seen earlier (see 2.1) of this essay, only register has been used so far, for describing texts.

51 These categories provide a conceptual framework for analysis. They are not, we should recognise, themselves kinds of language use. Genre (research report, business report, case-study) and register (the language of newspapers, legal language, the language of bureaucracy) strictly relate to each other and have "complementary" registers. Since the two scales are interdependent, a writer could select a genre that implies a high level of explicitness (like a business report) and at the same time select a register that demanded less explicitness like bureaucratic or legal language; in doing so, a writer must decide which criteria for explicitness he wishes to dictate for the linguistic choice (clear hierarchical development of message and support demanded by a report genre or implicit expression of the cultural values of impartiality, power and prestige associated with legal style).

Genre becomes a recognizable communicative event characterised by a set of communicative purposes identified and mutually understood by members of the professional or academic community in which it regularly occurs and most often highly structured and conventionalized. (Bhatia 1993: 13). 

specific lexis. A discourse community utilizes and hence possesses one or more genres allowing to use appropriately topic, form and functions and discoursal elements. But participation does not always entail assimilation to the group as it is shown in the case of a journalistic writing (e.g. case reports in the Times) may use discourse conventions typical of a specific group, without being assimilated to the group e.g., legal language without being assimilated into the legal community. He just uses topics forms and functions appropriately.

has been, comparatively, a great interest in legal language Register studies (see Mellikoff, Danet \& Bogoch, Kurzon, and others) and also socio-linguistic studies on the language of Economics and Management, see (Tadros, McCloskey, Merlini, etc.) There is relatively little interest in seeing how texts are perceived and categorized and used by members of the community.

\subsection{Language, Ideology and Common sense}

Both the language of the law and the language of management --as signs - reflect in their practice a position of power as each is the language of people connected with power who control the discourses and practices of their profession. and the ideological assumptions embedded in these discourses which come to be taken as common sensical. Hence the definition of Common Law (Roger Bird, Osborne's Concise law dictionary):

...It is the common sense of the community, crystalized and formulated by our forefathers...

If we try to follow the process of generation of meaning and concepts at different levels in their language and their practice reflects this position of power, in the sense that they can influence and control and determine discourses which become universal and common sense, we recognise that this is a significant complement to economic power, creating and enforcing unbalanced and unequal power relations discourse as in the example reported earlier (2.12.2), even in terms of its self-articulation, legal discourse is paradigmatically concerned with truth, both in term of evidence or verification and also more generally in terms of the definition or delimitation of power and powers in the discourse of the rights, duties, capacities and procedural forms.

the meaning of ordinary word when used in legal documents so e.g., discovery, used in the strict sense is... "the disclosure of one party to another of the existence of relevant documents which are or have been in his possessing, custody or power and further documents..." (in practice discovery is used to include both disclosure and subsequent inspection of documents).

Therefore linguists cannot provide any valid explanation for the use of legal jargon as it is the lawyers tool and the only way to communicate within the legal community and to interact and establish rules of behaviour that are mandatory for other social groups, as we have seen in the case for negligence (2.1).

Cases are part of the substantive law whose primary function is declaring the law, hence they have style and genre constraints whose conventions are strictly institutionalized, as 
in the case of negligence above, where a new important principle has been laid down; respect your neighbour, from which derives an obligation in case of alleged negligence. It would be inconceivable that it could have been framed and presented differently. If it had been it would not have been recognized by the other members of the legal community, the judges, lawyers, solicitors it was addressed to.

Nonetheless, they are allowed some freedom, but only in the non-strictly legal parts of the judgement obiter dicta and description of the facts, where a more personal style is possible.

In the case of the language of management and economics, economic power is located in the production of goods and commodities to be sold in the market, so people with power in the institution see their interest as tied to the capitalism.

Management is a comparatively modern practice and so the language is heavily influenced by advertising and news discourse where there are still conventions of style and genre: business report, memos, statements, business letter: each has a conventionalized use. The example of Section 2 , is lexically simple, as it contains only a small amount of technical terminology -results, prime sites, performance, turn-over- but nothing so specialized as to be outside the vocabulary of the average educated person. Some genuinely relaxed features more commonly associated with spontaneous speech (short active declarative sentences). This is also common in news language where written English is very informal but is affected by Novelty. Consonance with the value and attitudes shared by a newspaper and its readers and with the consensus in a given society. Relevance, is another important feature, relevant to the experience of large groups of reader (a financial news item can be given in terms of more or less money for the interest group involved: shareholders, ordinary man etc.) But also taking into account Gricean maxims, Eliteness, Brevity and Clarity also play important roles. The relevant theories expressed by the managment gurus are also reported and clearly stated, using buzz word such as downsizing, re-engineering, top-management and corporate cohesion.

General comprehension is a basic value together with Color to make it more clear and concise by maximizing its news value with a challenging title and "slangy" words (e.g., razzmatazz, muscling in on) suggesting participation and facilitating access.

\section{Summary and conclusion}

65 We assume that the competence of the linguist studying, for example, a legal text lies in discovering and describing linguistic features in the text and the competence of the legal scholar in contextualising the whole of the discourse which is realised by the text. The linguist is a non-expert where legal studies are concerned as, equally, the legal scholar is a non-expert in terms of linguistics but each is entitled to offer the other commentary on textual features (formal or functional) and, ultimately, we might expect the emergence of legal scholars or economic scientists who also possess expertise in linguistics and linguists with expertise in the law, and in their specialised field, within the legal process itself, the developing role of the forensic linguist (see Coulthard 1994).

These principles should guide the approach to texts bearing in mind to consider them in a wider approach where they work as systems of signs identified by semiotic factors and organising principle, according to the rhetorical function they perform. 
Some texts are the result of the process and the product the expression of the language of power. Common sense is the implicit philosophy in the practical activities of social life which sustain unequal power relations and hence influence the reading and interpretation of the discourses, practices and procedures connected to the profession providing a kind of logical framework for them.

Therefore neither the pure logic semantic approach of register analysis, considering and exploring variants of use (Field, Mode and Tenor) and user (dialects or idiolects) nor the pragmatic (analyzing speech acts, Implicatures and textual functions) shed enough light on the complex relationship of the production and explanation of texts.

Linguistics seeks to explain how sense is constructed in a language system; pragmatic, how sense is constructed in language use, semiotics is trying to ask whether we can construct any general theory of sense construction, one which is not confined to language or behaviour(like in psychology), but which provide a common theoretical foundation for the different disciplines of sense construction and contribute to their hypotheses and methodologies (Jackson 1995: 141).

We need a broader-based approach including the semiotic dimension; an interactive dimension in which there is a wider cultural context (social action, the speech community) to locate and understand texts and discourses. This global approach is needed to take into account all the variables of the communicative event (from social discourse, to intertextuality) to permit not only an analytic but also a critical reading of the text as the communication of a discourse community of some sort (legal or business community) which creates and imposes and communicates cultural values, meaning, concepts and practices and determines (inter and intra) discourses within the community and outside the community, giving them the imprimatur of common-sense (in the sense of the world-view implicit in Law and Economics).

\section{BIBLIOGRAPHY}

Bell, R. 1991. Translation and Translating: Theory and Practice. London: Longman.

Coulthard, M. 1992. Forensic Discourse Analysis. London: Routledge.

Danet, B. and B. Bogoch. 1994. Orality. Literacy and Performativity in Anglo-Saxon wills. In J. Gibbons, J. (ed.), Language and the Law.London: Longman, 100-135.

Fairclough, N. 1989. Language and Power. London: Longman.

Goodrich, P. 1990. Language of Law. London: Weidenfeld \& Nicholson.

Grice, H.P. 1981. Presupposition and Conversation, Implicature. New York: P. Cole Radical Pragmatics Academic Press.

Gibbons, J. 1994. The Language of the Law. London: Longman.

Halliday, M.A.K. 1975. Learning how to Mean. London: Arnold. 
Hoey, M. 1985. The Statute as Discourse and the Lawyer as Linguist. New York: Hornebeam Press Columbia.

Jackson, B.S. 1995. Making Sense in Law. Liverpool: Debora Charles Pubs.

Kurzon, D. 1985. “Clarity and Word Order in Legislation”. Oxford Journal of Legal Studies 5/2, 269-275.

Levison, S.C. 1983. Pragmatics. Cambridge: Cambridge University Press.

Mellinkoff, D. 1963. The Language of the Law. Boston: Little Brown.

Pierce, C.S. 1960. .Collected Papers of C.S Peirce. Cambridge, MA: Harvard University Press.

Resta, S. 1990. An Approach to Non-Literary Translation. Rome: Kappa.

Swales, J. 1993 [1990]. Genre Analysis. Cambridge: Cambridge University Press.

\section{ABSTRACTS}

With the expansion of the scope of linguistics -in the 1970s and 80s- beyond the level of the context-free sentence in syntax and the isolated word in semantics, interest in a broader textlinguistics has (inevitably) developed in which the word and the sentence are both seen as inherently context-sensitive components of a larger communicative unit; discourse. Such a reorientation has, necessarily, led to attempts at the creation of text-typologies and, in the longer term, comparative textology where different text types are compared and contrasted and their criterial characteristics are revealed. This paper -essentially a piece of 'work-in-progress' rather than a finished contribution to the field- shows how the micro-level techniques of discourse analysis and the more macro-approach of semiotics can be combined to reveal the similarities and differences in two strikingly contrasting text-types; the legal case-report and the management case-study.

La linguistique ayant, depuis les années 1970 et 1980 étendu son champ d'études, pour la syntaxe, au-delà de la phrase détachée de son contexte, et pour la sémantique au-delà du mot pris isolément, l'intérêt s'est porté, inéluctablement, vers une linguistique du texte, de champ élargi, dans laquelle à la fois le mot et la phrase sont conçus comme les composantes, indissociables de leur contexte, d'une unité plus globale de communication: le discours. Cette réorientation a conduit à des essais de construction de typologies textuelles, puis à de la textologie comparée, qui étudie contrastivement différents types de textes (ou genres), pour en dégager les critères caractéristiques. Le présent article - qui est pour l'essentiel le reflet d'un travail en cours davantage qu'un apport définitif - montre comment les techniques de micro-analyse du discours spécialisé et l'approche sémiotique plus large peuvent se combiner pour mettre en évidence les similitudes et les différences entre deux genres bien distincts: le compte rendu judiciaire et l'étude de cas en gestion des entreprises.

\section{INDEX}

Mots-clés: analyse du discours, discours du management, discours juridique, genre, linguistique de texte

Keywords: discourse analysis, genre, legal discourse, management discourse, text linguistics 


\section{AUTHOR}

SIMONETTA RESTA

Simonetta Resta est professeur d'anglais à l'Institut des langues de l'Université de Rome (Istituto di lingue, Facoltà di Economia, Università La Sapienza). simonetta resta@yahoo.com 